\title{
STRUCTURE OF THE WORKPLACE OR, SHOULD WE CONTINUE TO KNOCK THE CORNERS OFF THE SQUARE PEGS OR CAN WE CHANGE THE SHAPE OF THE HOLES?
}

\author{
THE HONOURABLE WENDY G. BAKER ${ }^{\circ}$
}

The author discusses the structure of the workplace in the legal profession from the perspective of a woman who has practiced law for fifieen years, who was on a recent task force reviewing gender equality in the legal profession and who is now a member of the Supreme Court of British Columbia. From this perspective, the author finds that workplace structures in the legal profession have changed very little in the past two decades. However, a number of factors are compelling the legal profession to rethink workplace structures: average incomes of lawyers have dropped in recent years as compared to other similarly educated Canadians; traditional areas of practice for lawyers are being encroached upon by other professionals and para-professionals; the ofientimes unpopular image of the profession amongst its clients and the general public; and the increasing presence of women in the profession and their male counterparts who also wish to break from traditional modes of practice. These factors are forcing members of the profession to begin to take advantage of the flexibility latent in the traditional legal work environment to alter the structure of the workplace. The author says these changes are necessary to better serve the needs of both lawyers and the democratic society it is their function to defend.
L'auteure examine la structure du lieu de travail des membres du barreau dans la perspective d'une femme qui pratique le droit depuis quinze ans; qui a récemment participé d̀ un groupe de travail sur l'égalité des sexes dans le système de justice et qui est maintenant membre de la Cour suprême de la Colombie-Britannique. A partir de cette perspective, l'auteure estime que les structures du lieu de travail ont peu changé au cours des dewx dernières décennies. Cependant, certains facteurs poussent la profession juridique à les repenser : le revenu moyen des avocats et avocates a diminué au cours des dernières années par rapport à celui des autres Canadiens de formation équivalente; les domaines jusqu'ici réservés aux membres du barreau sont présentement envahi par d'autres professionnels et para-professionnels qui projettent parfois une image peu flatteuse de la profession parmi la clientèle et le grand public; le nombre de plus en plus nombreux de femmes et d'hommes qui aspirent à des modes de pratique moins traditionnels. Ces facteurs forcent les membres de la profession $\dot{a}$ profiter de la flexibilité qui sous-tend leur environnement pour modifier les structures du lieu de travail. Selon l'auteure, ces changements sont nécessaires pour répondre aux besoins des avocats et avocates, et de la société démocratique qu'ils sont destinés à défendre.

\section{TABLE OF CONTENTS}

I. INTRODUCTION $\ldots \ldots \ldots \ldots \ldots \ldots \ldots \ldots \ldots \ldots . \ldots \ldots 21$

II. INDICATORS OF CHANGE $\ldots \ldots \ldots \ldots \ldots \ldots \ldots \ldots .824$

III. RATIONALE FOR CHANGE $\ldots \ldots \ldots \ldots \ldots \ldots \ldots \ldots \ldots 25$

IV. RESTRUCTURING $\ldots \ldots \ldots \ldots \ldots \ldots \ldots \ldots \ldots \ldots .627$

V. CONCLUSION ...................... 829

\section{INTRODUCTION}

Why are our workplaces structured the way they are? What are the factors which preserve the status quo? What are the forces propelling change? Does the structure of the workplace promote professionalism, or impede it? Can the legal profession adapt 
to accommodate the goals and aspirations of lawyers of every colour, gender, age, religion, nationality and sexual orientation?

Why, you may be asking yourself, should lawyers hear the views of a judge on these issues? Good question, and one I asked myself when I was invited to participate in this panel. Nothing is more irritating than having to listen to someone who has abandoned the field giving advice to the remaining team members on how they should play the game. I am a recent deserter; I was appointed to my court in May, 1993. I still have trouble remembering not to say "we" when speaking about the legal profession. I certainly never had all the answers to these complex questions while I was digging away in the trenches of my law firm, and no miraculous investiture of wisdom has occurred since my departure from practice.

However, there may be things about an old workplace that can only be appreciated from the perspective of a new one. I am reminded every day in the courtroom of how vital it is that Canadians receive high-quality legal services from the members of a truly independent profession which reflects the makeup of our diverse society. It is trite to say that without an independent bar, there can be no independent judiciary. It is also trite to say that without an independent judiciary there can be no rule of law, and without the rule of law, the freedoms and privileges that make Canadians the most fortunate of peoples will not long survive. However trite, these statements are true. People all over the globe envy Canadians their legal profession and their justice system. They come to Canada from the new nation-states of Africa and from the ancient nationstates of eastern Europe to try to learn the basic ingredients of a system of justice that we take for granted and too frequently malign.

This realization does not compel me to defend the legal profession or our system of justice against all criticism, or to overlook the flaws and cracks that, unchecked, may develop into chasms. To an extent, the independence of the bar and bench in Canada has never really been put to the test. We have not been asked to enforce the blatantly racist apartheid laws of South Africa, nor the race relations statutes of the Third Reich in Germany. Judges and lawyers are not regularly assassinated here for trying to root out corruption, as they are in some South American republics. Lawyers are not rounded up and thrown in prison for criticizing the government in power, as they have been in East Africa. We cannot know, and I hope we never will know, if we would meet those kinds of challenges to our independence or be found wanting. We have the luxury of coming to conferences like this to engage in an examination of the legal profession, knowing that we stand on a firm foundation in Canada. In the same way, however, that a prudent homeowner fixes the roof and cleans out the gutters on a sunny day in preparation for a possible deluge, the legal profession is wise to locate and remedy any cracks in the foundation that may not withstand future upheavals.

I have thought about the structure of the legal workplace from a variety of perspectives. One of these, the new perspective of my first year as a judge, I have already mentioned. Before my appointment, I practiced law for fifteen years with a large firm in the lower mainland of British Columbia. I enjoyed practicing law. I do not mean that I leapt eagerly out of bed and could hardly wait to get to the office each and 
every day of my career as a lawyer. Sometimes, for weeks at a time, I would wonder if this was the right career for me, whether I wanted to be doing this for forty years, and whether any well-adjusted human being would put up with demanding clients who do not pay their bills, the questionable tactics of some opposing counsel and the short attention span of some judges. Then there would be periods of weeks or months when the clients were appreciative and reasonable, opposing counsel were cooperative and competent, and judges not only saw the obvious merit of my submissions, but were courteous and even displayed a sense of humour. In those times, I thanked my lucky stars I had had the great good fortune to be allowed to enter a profession that offered interesting problems, a variety of work and the opportunity to make a more than decent living.

I gained another perspective from my involvement with the Canadian Bar Association, through which I had the chance to get to know lawyers from across the country and from every size of firm and every area of practice, and to hear from them about the things that make the practice of law both frustrating and fascinating. I developed a particular interest in the topic of career satisfaction for lawyers, recently the subject of considerable study and debate in Canada and the United States.

Finally, and I suspect this is the real reason I was selected for this panel, I had an eye-opening opportunity to view the legal profession and the legal workplace, from the perspective of hundreds of women who practice law and many more who are clients of lawyers. In 1991 and 1992 I was a member of a task force appointed by the Law Society of British Columbia to explore the topic of gender equality in the justice system. One of our mandates was to consider gender equality in the legal profession. Later, in a much less direct way, I followed with interest the work of the Canadian Bar Association Task Force on Gender Equality in the Legal Profession. Their report' built upon and developed the themes which were identified with unsurprising similarity by earlier reports. ${ }^{2}$ These reports, and a myriad of others published in jurisdictions across Canada and in the United States, addressed the impact of the structure of the legal profession and the legal workplace on the lives of female lawyers, and the impact of the entry of increasing numbers of female lawyers into the profession. Some of these reports also addressed these issues from the perspective of lawyers whose race, religion, national origin, colour or sexual orientation differs from that of the majority of lawyers.

1 Canadian Bar Association Task Force on Gender Equality in the Legal Profession, Touchstones for Change: Equality, Diversity and Accountability (Ottawa: Canadian Bar Association, 1993) [hereinafter Touchstones for Change].

2 See e.g. Law Society of British Columbia Sub-Committee on Women in the Legal Profession, Women in the Legal Profession (Vancouver: Law Society of British Columbia, 1991). See especially J. Brockman, "Encountering Barriers and/or Moving On: A Survey of Former Members of the Law Society of British Columbia" Appendix 3 in Women in the Legal Profession, ibid. See also American Bar Association Commission on Women in the Profession, Lawyers and Balanced Lives: A Guide to Drafting and Implementing Workplace Policies for Lanyers (Chicago: American Bar Association, 1990); Law Society of Upper Canada Standing Committee on Women in the Legal Profession, Transitions in the Ontario Legal Profession: A Survey of Lawyers Called to the Bar Between 1975 and 1990 (Toronto: Law Society of Upper Canada, 1991); Law Society of Alberta Committee on Women in the Legal Profession, Women and the Legal Profession in Alberta (Calgary: Law Society of Alberta, 1992). 


\section{INDICATORS OF CHANGE}

It cannot be said that the news was all bad; far from it. Those who pine for the good old days of lawyering should consider the issue from the perspective of women and minorities. You have probably heard lawyers and judges reminisce about those bygone days when apparently all lawyers were competent and highly ethical; everyone did vast amounts of pro bono work but still managed to earn huge incomes and frequently go on extended vacations. Oh, I forgot the part about how lawyers (and judges) used to be universally popular with their clients and the public, and never had to suffer the slings and arrows of an outrageous (and outraged) press. However rosy the historical glasses, women and minorities have little to contribute to these discussions; they simply were not there. This is changing. As Justice Abella said in a speech at a Law Society of Upper Canada Continuing Legal Education Program in 1986:

I understand full well that this is a profession which bends only creakingly to change, but change has come. Not all lawyers wear three piece suits, blue and grey are not the only sartorial choices, not everyone wants to do estates or real estate or corporate work, not everyone is part of the old boy network, not everyone comes from an economically comfortable home, not everyone is able-bodied, not everyone is white, and not everyone is male. In short, the profession is becoming more reflective of the community it serves. This change can be the profession's greatest strength if it acknowledges and draws on the concerns, aspirations and talents of its newest recruits. ${ }^{3}$

The scale of the change in the legal profession in the last half-century was brought home to me in a very real way a couple of years ago when I met Mrs. Sherwood Lett, whose late husband had been Chief Justice of British Columbia for a time. Mrs. Lett told me a story about having accompanied her husband to Quesnel where he was hearing a criminal trial involving a charge of rape. At that time, she told me, it was not uncommon for the wives of judges, who rarely worked outside the home, to travel with their husbands on assize. She sat in the back of the courtroom listening to the evidence for a couple of days, but on the third day was told by her husband that she should not attend, because the nature of the testimony expected that day would be too shocking and disturbing for a woman. In a similar trial today, it would not be uncommon for the judge, Crown counsel and defence counsel to all be women.

Women have entered the profession in large numbers and many are thriving in it. But can it be said that women have had any real impact on the structure of the legal workplace as they found it in the mid-70s, when large numbers of women first began to graduate from Canadian law schools? Have women, the square pegs, forced the workplace to change to accommodate their "differentness," or have they adapted to the workplace, accepting the structure as inherent to the practice of the profession of law? For the most part, I think the latter is true. In some strange Darwinistic evolution, many of us adopted protective colouring, learned to fit in, to get along and to play by the rules. 
Many women who entered the profession in the 70 s thought it was simply a matter of time until women would make their mark and cause the workplace to adapt. For a long time I believed in what I call the "feminist critical mass" theory. That is, once there were enough women in the profession, we would make a difference, and real, fundamental change would necessarily result. And things have changed for the better, with the active support of many male lawyers who welcomed the changes and saw in them their own opportunities for growth.

However, change has come slowly and at great cost. Many women, especially women with children, have simply left the profession, unwilling or unable to conform. Some women have created their own options; for example, all-women law firms or smaller firms in which like-minded individuals have been able to design a working environment to meet their own and their clients' needs. Women, in disproportionate numbers, have chosen to work as corporate counsel, or in government, where they have found the work culture and environment less hostile. Even in these settings, women who aspire to leadership roles have had difficulty. The women lawyers who survived learned to meet or beat their male colleagues at their own games. Unfortunately for the vast majority of male and female lawyers, the games have remained pretty much the same, with the same basic rules.

In many ways, for many lawyers, the legal workplace has changed little in the past two decades. Lawyers work in offices in business districts. Their clients come to them. Most legal workplaces are open from nine to five, or eight to six on weekdays, with the expectation that many more hours will be devoted during evenings and weekends. Most expect the lawyer to come to the workplace every working day. The vast majority of lawyers are expected to work full-time throughout their careers. Children are invisible in most legal workplaces; they are neither to be seen nor heard of, at least not during working hours. Quantity of work produced is more easily measured, and as a result, more highly compensated than other contributions made by lawyers. Time is the only marketable commodity of the lawyer in private practice. More income can be generated only by working longer hours. How good a lawyer you are can be measured by how much money you make. Being overworked and not having had a vacation for three years is a badge of honour. The adversarial system is the best way to achieve a just result, and in that system, lawyers are champions for their clients, like gladiators of old. If you can't stand the heat, get out of the kitchen, don't try to fix the stove. Never say you're sorry, and never let them see you sweat.

\section{RATIONALE FOR CHANGE}

Why change? Most lawyers make a living; some make a very good living. If women are leaving the profession in large numbers after a few years, there are always more young law school graduates knocking at the door. So what if a lot of male lawyers are also unhappy, and alcoholism and family breakdown result? Some would say those people were probably not cut out for the profession anyway. And what of the escalating insurance claims and complaints to law societies and politicians by dissatisfied clients? Merely evidence that Canadians are becoming more litigious? 
Despite these attitudes, many lawyers, among them the leaders of the profession, are beginning to think that change must come and at a faster pace. There is at least a perception that the income of lawyers, in real and comparative terms, has declined in the past two decades. While most lawyers make adequate incomes, and a minority do very well, compared to other Canadian professionals with similar training and experience incomes have slipped. In order to hold their own, lawyers are working longer hours, with less time for their families and their personal lives. While lawyers are still major contributors of volunteer time to their communities, they seem to be succeeding professionally and financially at greater and greater personal cost. This time starvation is most acutely felt by women who are attempting to combine practice with parenting, but it is not unique to them. Lawyers perceive that they are working more and earning less, and they are asking themselves if there is a better way.

Lawyers, like judges, have never been universally popular and are unlikely to get fan mail or to become media darlings. Clients are often in trouble when they come to a lawyer, or they are trying to stave off future problems by ordering their affairs. Nobody likes to pay legal fees. In every lawsuit and in many commercial transactions, somebody comes out feeling as if they have been bested. Often, even the successful party is unhappy with the result, the time it took to achieve the result, or the cost. Unpopularity can be borne, however unhappily. Recently, however, there is greater reason to be concerned that the lack of understanding of what lawyers do and of the importance of their work in a democratic society may place lawyers' independence and self-governance at risk. I do not suggest that merely changing the structure of the legal workplace will solve this critical concern; but the legal profession must continue to work to ensure that charges of elitism, exclusion, inaccessibility, unaccountability, and racial, religious and gender bias are without foundation and that the structure of the profession and the legal workplace is inclusive and promotes the delivery of costeffective, high-quality legal work. If lawyers are not perceived to be the champions of the underdog, even by underdogs, the foundation of self-governance and independence of the profession so essential to our system of justice, may be eroded. In addition, lawyers have been losing historical professional turf, and need to find new turf. Many areas of practice, once exclusively within the purview of lawyers, have been encroached upon by other professionals and para-professionals, or have become so unprofitable that lawyers have been forced to rethink the way they practice law and the way they structure their practices.

All of these factors are propelling change and reconsideration of the structure of the profession and of the legal workplace. I think that the profession will meet these challenges and that constructive reform has already begun. The legal profession in Canada has demonstrated a willingness to engage in critical self-examination. What other profession has been willing to ask itself if gender or racial bias exists in the profession and to commit itself to reform when the problems have been identified? Not only did law societies and bar associations across the country commit their members' funds to these studies and to the work required to follow-up on the recommendations, but hundreds of lawyers and law firms donated money. Hundreds more participated by making presentations, gathering information and serving on task forces and committees. This generosity and openness reflects not only the influence of women in the profession 
today, but the commitment of male and female lawyers and their governing bodies to maintaining the high standards and ideals of the profession. Law societies, bar associations, law schools, legal educators, law departments and law firms have begun to act on the recommendations.

Some consider the pace of reform too slow, but change is occurring. Law societies have introduced reduced fees for part-time practitioners and non-practicing members and they have reduced barriers to re-entry for lawyers returning to practice after an absence for child-rearing. New ethical rules have been promulgated, making it clear that racial and sexual discrimination or harassment are not to be tolerated in the profession. Law firms have implemented parental leave policies and flexible work schedules, and have put in place mechanisms to address sexual harassment. Nothing has more clearly demonstrated the changes in law firms than the fact that some young women have felt confident enough to bring sexual harassment complaints forward, without fear of the indirect, negative consequences which surely would have been visited on such complainants in the not very distant past.

\section{RESTRUCTURING}

One of the strengths of most legal workplaces is a basically flat structure. The partnership model employed by most private law firms is not very hierarchical, having at most two or three levels. Even corporate law departments have comparatively flat "command structures." This results from the historical rules of the profession and the fact that each lawyer, as a professional, is individually accountable for his or her own work. Of course, lawyers work in teams, especially in large law firms and legal departments, and associates and articling students work under the supervision of more experienced lawyers. But each legal professional remains directly accountable for his or her own work. In my view, this lack of formal hierarchy in the legal workplace should make it better able to adjust rapidly to accommodate the changing needs of clients and lawyers.

The time of day or location of legal work need not affect its quality or timeliness. Clients and colleagues do need and expect to be able to contact a lawyer with reasonable ease. But that does not mean that a lawyer needs to be in his or her office during day-time hours every day of the week. With the increasing use of technology, lawyers can work at home, in clients' offices and in satellite offices near their homes. Often the only barrier is a resistance to change. I could never understand, as a litigator, the objection of some law firms to lawyers who want to work part-time for reduced income, so long as the lawyer is flexible in his or her schedule. The argument that a lawyer must be available to his or her clients all day every weekday simply does not make sense when you know that during a trial a litigator is highly inaccessible to other clients, and that during a long and complex closing, a solicitor must give priority to one client's affairs. Most clients accept these realities, so long as their lawyer ensures their needs are otherwise promptly addressed and given priority when necessary.

That most lawyers today account for time spent on individual projects or files and that most law firm billing and information systems provide a means of "valuing" the 
lawyer's productivity in at least a quantitative sense, are both weaknesses and strengths of the structure of the legal workplace. The remuneration of lawyers, especially partners and associates in private law firms, is often based solely, or primarily, on this measure of productivity. Although the imposition of fixed billing quotas may constitute adverse effect discrimination (an issue raised in Touchstones for Change, ${ }^{4}$ which I will leave aside in this address), the flexibility of this approach to remuneration should allow law firms to permit lawyers to work part-time or flex-time, to job-share, or to reduce temporarily their output in terms of billable hours in order to accommodate other responsibilities, such as childrearing.

Of course, law firms must be profitable. But the reluctance even to consider experimenting with alternate or flexible work schedules is, in my view, fuelled more by stubborn adherence to tradition than by an informed consideration of the potential impact of flexible work schedules on the bottom line. There is a lack of imagination, a dog-in-the-manger attitude in some law firms that presumes change is bad and that the present structure of the legal workplace is dictated by some natural law or divine edict, rather than being the product of nineteenth and early twentieth century management theory.

The phrase "law office management" was, until the last two or three decades, a virtual oxymoron. In most small law firms, and even in some large firms, law office management was conducted by one or more of the partners, who volunteered or were elected to manage the firm off the corner of their desks, while also carrying a full caseload. This volunteer management was often supplemented by a member of the staff, without benefit of management training, who had moved from the ranks of the secretarial staff to the duties of "office manager." Even today, law firm management is barely out of its infancy and into its troubled adolescence. Many of the experiments in law firm management of the past two decades, especially in large, urban law firms and corporate law departments, have produced unfortunate results. Attempts to impose on the law firm a management structure borrowed from large hierarchical corporations have been, in my view, largely unsuccessful and detrimental to professionalism. There are fundamental differences, or there should be, between firms of lawyers, each an independent professional accountable to his or her own clients and profession, and a factory which produces tires.

However, things are getting better. While I am unaware of any law school or other post-secondary institution in Canada providing a diploma or degree program in law firm management, there are associations of law office managers, conferences, seminars and journals dedicated to improving the quality of law firm management. As well, law firms are beginning to realize that to maximize the potential of the human resources they offer to their clients, they must manage those resources well and fairly. Many of the concerns lawyers have about the places in which they work could be solved by effective, consistent and innovative management. Law schools, law societies and continuing legal educators should continue to emphasize effective practice management and a high standard of professional responsibility. The hiring of "practice advisors" by 
law societies is a very positive development. Lawyers are sometimes successfully sued because they did not know the law, but far more often the problem is a lack of organization and management, or a failure to recognize the professional duty owed to the client.

Some lawyers, and not just young ones, are openly questioning the value system of the traditional legal workplace. Many law firms have been confronted by top candidates for articling positions, or highly qualified and valued associates who have said, "This life is not for me, making a lot of money is not my only goal." Of course, lawyers want to earn good incomes, and they deserve to. After seven or eight years of university and a year of articling, a newly-called lawyer has had a long period of deferred income. She will have heavy responsibilities for her clients' lives and assets. She will rarely leave the office without a client's file on her mind or in her briefcase. Her vacation will be interrupted by phone calls from clients with urgent problems. She will wake from a sound sleep thinking of that approaching limitation deadline. Accepting responsibility for other people's problems is what lawyers get paid to do and they deserve to earn a good living. But many lawyers are questioning money as the only goalpost. The concept that, "I am a good lawyer if I bill a lot and earn a lot, and I am not a good lawyer if I don't," is not accepted as readily as it once was. Many lawyers have set other goals for themselves.

The beauty of the legal profession is that it does offer options, if lawyers are willing to accept that they can succeed in their profession in many different ways. There are partnerships, associations, office-sharing, referral networks, national and international mega-firms, in-house counsel, corporate law departments, teaching and research, public interest law, legal journalism, law office management and judging. This is by no means an exhaustive list. The design of the legal workplace is limited only by economics and ethics. Lawyers have a lot to lose as a profession if they let the traditional structure of the workplace govern them, rather than letting their goals and aspirations dictate the structure of the places in which they work.

\section{CONCLUSION}

What remains to be done? Here are some thoughts. The outstanding work of the task forces, committees and individuals who have addressed the concerns of women and minorities about the accessibility and openness of the profession should not be wasted. Lip service is not enough. Identifying the problems, even identifying possible solutions, is not enough. The solutions have to be tested and evaluated. We must accept that there will be resistance and that there will be failure. We must find what seems to be working and build on it. We must adapt and move forward. Just because we've been organizing law offices in the same way for centuries does not mean that it is the right way or the only way. For centuries, people thought the world was flat, but that did not make them right.

Lawyers should worry less about their popularity as a profession and more about whether Canadians and their governments understand the essential role of an independent bar in preserving the rule of law. I have been encouraged by what I have 
seen in law classes taught in high schools in British Columbia, but many students and most Canadians have no exposure to these important concepts. Lawyers and their associations should continue to promote public awareness and understanding of our legal system and the essential features of a society governed by the rule of law. Lawyers should celebrate the accomplishments of their profession and recognize the incredible strength to be found in its growing diversity.

I have often said that if the legal profession did not exist today, it would be created by society tomorrow. People may disparage lawyers, tell unflattering jokes at their expense, emphasize the occasional defalcations or breaches of ethical standards, and point out the profession's shortcomings. Indeed, many of these items were documented in the gender equality reports to which I have already referred.

Yet, when civilized people have problems, lawyers and the justice system provide an acceptable way to solve these problems and minimize conflict. When people think their rights are being trampled or their privileges as Canadians are in jeopardy, they call lawyers.

This does not mean that lawyers should not welcome constructive change in their workplaces and in their profession. Lawyers (and those of us who are former lawyers) should stop thinking of twenty reasons why something new may fail and start planning for successful change. We should focus on the problems and shortcomings of the profession for constructive purposes only, so that the need for change may be demonstrable and solutions may become apparent. The structure of the workplace must adapt to allow the profession to respond to the rapid changes that occur in the world between the time each of us gets out of bed each morning and returns to bed each night. If we succeed, the profession will continue to fulfil the essential role it has played in making Canada an enviable place to live and practice law. 